\title{
Maximizing The Value Of Your Small Business
}

Terry Mullins, (E-mail: tmullins@ju.edu), Jacksonville University

Michael Adam, Jacksonville University

Barry Thornton, Jacksonville University

\begin{abstract}
This paper offers business owners a step-by-step valuation process for establishing the fair market value of their firms and stresses the importance of preparing for the due diligence process.
\end{abstract}

\section{INTRODUCTION}

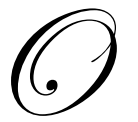

wning a business represents one of the most effective ways to build personal wealth. There are approximately five million small privately-owned businesses in the United States, accounting for approximately $90 \%$ of all business units. Furthermore, these closely-held firms generate nearly $60 \%$ of total U.S. employment and account for almost $80 \%$ of all new jobs created. Additionally, these firms generate more than $50 \%$ of the nation's GDP while accounting for $65 \%$ of all wages paid in the U.S. (Graham \& Daly, 1994).

Almost all closely-held businesses created by the baby boom generation will lose their primary owner to either death or retirement by 2015 , resulting in approximately $\$ 400$ billion of net worth being shifted to a new generation, the largest inter-generational transfer in U.S. history (Gale \& Scholz, 1999). Unfortunately, many privately- held businesses will fail to generate full value when sold by their founders or heirs.

In a recent survey of small, family-held firms, 50\% of CEOs had not yet chosen a replacement, put a written succession plan in place, or developed an exit strategy (U.S. Bureau of Census, 2005). This is significant since fewer than 1 in 3 family firms survive to the second generation and not even 1 in ten makes it to the third generation (American Institute of CPA, 2005).

Comfortable with informal and unexamined management practices, many owners do not make the effort to position their businesses to sell for full value. The owners of privately-held firms frequently employ short-term strategies designed to minimize current taxes or achieve other personal objectives that undermine the value of their businesses. Value creation, however, is as important for small, privately-held firms as it is for their larger counterparts (Wolosky, 2005). This paper uses a step-by-step process to show owners how to position their businesses to sell for maximum value.

\section{UNDERSTANDING DIFFERENT TYPES OF BUYERS}

The market for privately-held firms is limited and segmented with potential buyers falling into four primary groups: liquidators, owner/operators, strategic buyers, and investors. Each group has a different set of needs, motive, and objectives. Sophisticated sellers adopt different marketing strategies for each market segment.

The first type of buyer, the liquidator, seeks a troubled or bankrupt firm that can be bought at a deep discount. Hoping to salvage salable assets, the liquidator is willing to pay the least of any potential buyer for a firm. Unless the firm is in severe trouble and time is of the essence, the business owner should avoid selling to a liquidator.

The second type of buyer, the owner-operator, will be concerned with price, the location of the business, the ease of operation, and stability of cash flow. The reasonableness of the price is likely to be judged by the purchaser's 
own pocketbook. Since the potential buyers in this category may have little experience in the industry, ease of operation may also be an important consideration. Owner-operators generally seek businesses located near where they live or hope to live in the future. If the business is difficult to operate or if earnings fluctuate significantly, the owner-operator may not make a good prospect for your business.

The third type of buyer, the strategic buyer, is a corporation that buys a business to implement its strategies more quickly or cheaply. Such buyers are usually interested in obtaining the firm's customer base, using the firm's location to expand geographically, or acquiring proprietary technology. Since strategic buyers are typically more sophisticated and well funded, they can make very attractive potential buyers.

The final type of buyer, the investor, is perhaps the most selective of prospective buyers, evaluating a business on its ability to generate cash flows that meet pre-established criteria. Since an investor is not interested in running a business or merging it with another firm, he or she is the buyer most interested in the quality of the business as a going concern. While the investor may be interested in redeploying assets or increasing the efficiency of the firm, he or she is not interested in dismantling the firm or in running it personally. Therefore, the investor will pay a premium for a firm that has a well-defined market niche, an effective strategy and a competent management team.

\section{HOW BUSINESSES ARE VALUED}

\section{Salvage Approach}

Troubled firms, those with serious losses and poor prospects, attract buyers who are more interested in liquidating the firm's assets than in running the business as a going concern (Devaney, 2003). Liquidators are usually tough negotiators who buy assets at a deep discount. On the positive side, a liquidator usually makes decisions quickly and generally pays cash.

Obviously, most business owners do not want to sell to a liquidator. However, a partial liquidation may be in order if it adds cash to the assets, simplifies the balance sheet and makes a positive story easier to tell when it comes time to sell the remainder of the business as a going concern.

\section{Multiplier Approaches}

In most industries there is a rule of thumb for converting earnings or revenues into a price for a business (Desmond, 1991). This method uses a multiplier to arrive at a price. While this approach has the virtue of simplicity, it may result in either undervaluing or overvaluing the business (Brodsky, 2005; Hall, 2004).

In the first case, the multiple is calculated by dividing the average selling price of a group of firms in an industry by the average earnings of those same firms. Similarly, one can divide average selling price by the average revenues of the firms to find a multiple of revenues.

Given that the owners of privately-held firms have strong motives for reducing tax liabilities, the earnings estimates for such firms are often inaccurate and unreliable. Since the owners control discretionary expenses of the firm, earnings are frequently underestimated. Revenues can also be misleading if owners are not scrupulous in reporting cash transactions. Furthermore, looking at revenues without also considering cost can produce a distorted view of the value of the firm.

Better than average firms should be sold at multiples higher than the industry average. Conversely, below average firms should be sold at lower multiples. Most of those who use one of the multiple approaches do not make such adjustments. 


\section{Discounted Cash Flow Approach}

The discounted cash flow method of valuation is more sophisticated than techniques that rely upon industry multiples or other approaches. This method allows one to value a business as an investment, taking into account the size and timing of cash flows as well as the risk associated with their realization (Devaney, 2003). Buyers belonging to our "investor" category will almost certainly use the discounted cash flow method. While "strategic buyers" may use this method, they will also give weight to strategic considerations.

Different procedures are used in capitalizing a company's earnings to find value, but the underlying concept is always the same - determine a "normalized earnings" and capitalize it at some rate of return (the capitalization rate). Although the discounted cash flow method is not without problems, it generally provides the most defensible estimate of a firm's value. Among the problems that must be solved is the appropriateness of using the firm's current reported earnings versus future cash flows.

Critics argue that a firm's reported earnings can easily be manipulated within the boundaries of generally accepted accounting principles. This can result in material differences in the valuation estimate with no fundamental difference in the intrinsic value of the firm. One approach to overcoming this problem is to focus on the present value of the firm's free cash flows. Under such an approach, a firm's economic or intrinsic value is equal to the present value of its free cash flows discounted at the company's cost of capital, plus the value of the firm's non-operating assets. Examples of non-operating assets include such items as excess investments in marketable securities and the amount by which the firm's pension fund is over-funded.

An important part of this valuation procedure is determining the appropriate discount rate, which may be thought of as the required rate of return for the firm's primary stakeholders. For both publicly-traded and privatelyheld firms, the discount rate is well-approximated by the weighted average cost of capital.

Unfortunately, it is more difficult to determine the appropriate discount rate for a privately-held firm for two reasons. First, privately-held firms are held to less rigorous accounting standards than their publicly-traded counterparts. Second, privately-held firms are not required to disclose their financial statements, as are publiclytraded firms.

\section{CREATING A MARKETING PLAN FOR THE BUSINESS}

\section{Maximizing Reported Income And Modifying Financial Statements}

With publicly-traded firms, management has every incentive to maximize the firm's value in the eyes of shareholders. Since that value is calculated and published every business day as the stock price, managers continuously strive to increase sales, earnings and cash flow. Tax minimization strategies are not primary objectives for the managers of publicly-traded firms, but such is not the case their privately-held counterparts. Many business owners employ tax minimization strategies that result in the undervaluation of the firm.

Many discretionary expenses appear on the books of privately-held firms. In the areas of travel, expense accounts, company cars, aircraft, memberships and company-owned real estate, these owners may incur expenses primarily for the purpose of decreasing taxable profits. If family members are employed by the firm, payroll costs may be higher than a purely economic calculus would justify.

Unfortunately, strategies that artificially reduce taxable income will result in an undervaluation of the firm, regardless of the valuation method used. Efforts to rectify this problem by restating financial statements only makes matters worse by calling into question both the integrity of the firm's owner and the credibility of his or her other representations to the potential buyer. 


\section{Increasing The Strength Of The Management Team}

Many owners manage their businesses with a hands-on approach, reserving all but the most minor decisions for themselves. This suggests that such owners are the only ones who know the business inside-out, making them irreplaceable. If the prospective buyer is an "investor," the value of the business is decreased by an owner who cannot delegate or develop any depth of management within his or her team.

Small firms frequently have less extensive management training and development programs than larger firms. Consequently, many managers in these firms learn the majority what they know on the job. As a result, small, privately-held firms frequently have weak management teams with uneven levels of training, experience, expertise and competence. An owner planning to sell his or her firm should invest in strengthening the management team.

\section{Improving Operational And Control Systems}

McKinsey \& Co. (2005) found that investors are willing to pay a premium of up to 20 percent on shares of enterprises known to have a governance framework in place. A well-managed company operates predictably, based on standard operating procedures and a set of management and accounting controls. Many smaller businesses have not documented their operating systems nor do they have effective management controls in place. When conducting due diligence, a buyer may modify the value placed on the firm if the operating and control systems do not function smoothly. When preparing to sell the business, the owner should make certain that effective control systems are in place and well documented.

\section{Preparing For Due Diligence}

Actions undertaken by the buyer to check the veracity of representations made by the seller are referred to as due diligence. The seller needs to prepare for this process by assuring that there are no serious legal impediments to the sale, that accounting statements actually capture the performance of the business, and that physical and financial assets mirror current economic realities (Smith \& Smith, 2005).

Before the beginning of the due diligence process, the owner needs to remove any legal clouds over the business. Potential legal problems, such as product liability, employment discrimination, or hazardous waste problems uncovered during the due diligence process may significantly lower the valuation of the business. Serious legal liabilities may make it impossible to sell the firm.

The financial statements typically prepared for the owner of a privately-held firm are seldom adequate for the due diligence process. Since unaudited financial statements frequently contain unnecessary expenditures and may not fully show all income to the business, these statements generally need to be modified to be consistent with generally accepted accounting principles (GAAP).

In particular, due diligence would require the recasting of the financial statements in a pro forma format where all values are restated to reflect current economic realities, and certain non-cash items, such as revenue recognition, are closely examined. Pro forma financials statements must be adjusted to "wring out" the effects of excessive family member salaries, unreported income, excess cash, the substitution of firm debt for personal indebtedness, and non recurring income or expenses.

To maximize the value of the firm, a clear distinction needs to be made between salaries and dividends. Salaries are compensation for professional services rendered to the firm and should be treated as operating expenses. Dividends are returns on equity capital invested and determine the value of stockholder equity. The separation between owners and managers in publicly traded firms makes the distinction between salaries and dividends clear. 
However, the owner of a private business is often the firm's manager as well as its only equity investor. As a consequence of adopting a tax-minimizing strategy, many business owners either do not pay themselves a salary or underpay themselves. However, at the time of the sale, the owner's managerial services need to be accurately reflected in payroll expenses.

As part of the due diligence process, both physical and financial assets need to be examined and evaluated. The existence and condition of physical assets such as land, buildings, equipment, raw materials, and inventory need to be verified and assigned values. The verified worth of such assets needs to be compared to their book values. Similarly, financial assessments need to be examined and valued in terms of today's economic realities.

\section{SUMMARY}

The unique characteristics of small, privately-held firms make it difficult for owners to sell their businesses for full value when they retire or wish to move on to other opportunities. This paper provides advice to business owners concerning buyer segmentation, valuation approaches that may be used to determine the price of the firm, and marketing strategies likely to appeal to each segment of the market.

The paper groups potential buyers into 4 categories: liquidators; owner operators; strategic buyers; and investors. The valuation methods discussed included salvage value, various multiplier approaches, and discounted cash flow methods. The strengths, weaknesses, and appropriateness of each method was discussed.

To prepare the businesses for sale, owners were advised, first, to structure income statements and balance sheets to conform more closely to generally accepted accounting principles (GAAP). Second, owners were advised to strengthen their management teams, improve their operational and control systems, and prepare for due diligence. The final step was to prepare the marketing plan that targeted the market segment most likely to buy the business at a price favorable to the seller.

\section{REFERENCES}

1. American Institute of CPA. (2005). Private Company Financing Reporting Task Force Report. New York, NY.

2. $\quad$ Brodsky, N. (2005). What's Your Business Really Worth? INC Magazine. 55-56.

3. Desmond, G. (1991). Handbook of Small Business Valuation Formulas and Rules of Thumb. $3^{\text {rd }}$ ed. Camden, ME: Valuation Press.

4. Devaney, M. (2003). Planning a Small-Business Valuation and Sale. Journal of Financial Planning, 56-63.

5. Gale, W. G. and Scholz, J. K. (1999). Intergenerational Transfers \& the Accumulation of Wealth. UCLA Economics Working Paper \# 624, UCLA Department of Economics.

6. $\quad$ Graham, B. and Daly, M. (1994). Small Business Statistics. Sage Publication LTD.

7. Hall, S. C. (2004). Applying Income-Approach Business Valuation Methods to Professional Practices. Journal of Financial Service Professionals, 91-99.

8. McKinsey and Co., Koller, T., Goedhart, M. and Wessels, D. (2005) Valuation: Measuring and Managing the Value of Companies, $4^{\text {th }}$ ed. New York: John Wiley \& Sons.

9. Smith, H. and Smith, T. (2005). Family-Owned Business Valuation is More Art Than Science. Financial Executive, 21, 3, 18.

10. Wolosky, H. (2005). The Widening and Changing Scope of Valuation Services. Practical Accountant. 3138.

11. U.S. Bureau of the Census. (2005). Advocacy Funded Research. Joel Poppin \& Company \#211. U.S. Department of Labor, Bureau of Labor Statistics, U.S. Department of Commerce. 
NOTES 